\title{
GENDER RELATIONS IN SINGAPORE MALAY DUAL-INCOME HOUSEHOLDS: (UN)CHANGING VIEWS AND PRACTICES
}

\author{
Suriani Suratman*
}

\begin{abstract}
Over the last four decades the labour-force participation rate of women in Southeast Asia has been steadily increasing. While gender relations are changing in the public sphere as more women play dominant roles in the employment sector, whether gender relations in the domestic sphere are changing is rather ambiguous. In this article, the author looks at gender relations in Singapore Malay dual-income households. She shows that there are existing cultural perceptions of Malays regarding the roles of women and men in the family: i.e. women see to care-giving and men see to breadwinning. She also argues that parallels of this perception can be found at the state level as well. The Singapore government too is of the view that the primary caregiver in the family is the woman. The author illustrates this by using the example of the discourse on the 'supermom' in Singapore to show the government's expectations of women's role as mother. There is external support which makes Malay women affirm their maternal role. In conclusion, the author suggests that Malay women's and men's decisions around the division of labour must be conceived within the wider framework of society. Explanations for persistence of unequal division of labour in Malay dual-income households must take into account state views of gender roles.
\end{abstract}

\section{Introduction}

For quite some time, the labour force participation rate of women in Southeast Asia including Singapore, has been steadily increasing. Women are making the choice to stay employed after marriage and childbirth. ${ }^{1}$ Malay women in Singapore too are making the choice to be employed. Consequently, the labour force participation rate of Malay women is steadily increasing. While there are Malay women who are leaving the work force after getting married, about $46 \%{ }^{2}$ continue to stay employed. Studies on employed women in the United States, Australia and Europe show that

* Suriani Suratman is Senior Lecturer at the Department of Malay Studies, National University of Singapore (NUS). 
apart from having to fulfil demands at their workplace, women are also responsible for work at home. ${ }^{3}$ Furthermore, findings from these studies show that women see to the bulk of the household work. The view that women are the primary caregiver remains.

Findings from my study show that Malay women in Singapore are seeing to the bulk of household work. ${ }^{4}$ Nevertheless, Malay men are assisting their wives in carrying out household work. There seems to be some change in practices of sharing out work in Malay households. This change however depends on three factors: women's time constraints, notions of skills in carrying out tasks, and availability of partners to carry out tasks. ${ }^{5}$ I also found that the women in my study are the ones who decide what tasks can be transferred and to whom these tasks can be delegated to. ${ }^{6}$ As such Malay women's notions of women's and men's work matter in defining what her husband can or cannot do. It appears that Malay women's maternal gate-keeping is inhibiting Malay men's involvement in household tasks and therefore determining more equal household division of labour.

In this article, I show that there are existing cultural perceptions of Malays regarding the roles of women and men in the family: i.e. women see to care-giving and men see to breadwinning. Malay women who are employed do not relinquish care-giving tasks. More importantly I argue that parallels of this perception can be found at the state level. The Singapore government too is of the view that the primary caregiver in the family is the woman. I illustrate this by using the example of the discourse on the 'supermom' in Singapore to show the government's expectations of women's role as mother. Indeed as Allen and Hawkins ${ }^{7}$ also point out, there is external support which makes Malay women affirm their maternal role. In conclusion, I suggest that Malay women's and men's decisions around division of labour must be conceived in a wider framework of society. Explanations for persistence of unequal division of labour in Malay dual-income households must take into account the state's views of gender roles.

\section{Malay Women's Participation in the Labour Force}

\section{Industrialisation and Female Labour Force Participation}

When the Singapore government embarked on its industrialisation journey soon after independence in 1965, women were highly encouraged to participate in its labour force. Rapid industrialisation in this period had caused a labour shortage to the extent that foreign workers had to be employed. ${ }^{8}$ The concern of the government then was how to increase the country's supply of labour. The focus was directed at young women who were described by the then Prime Minister Lee Kwan Yew as "underutilised". 
Women were drawn into the labour force - albeit in the low income jobs. The female work force was predominantly in the labour-intensive manufacturing industries such as electronics and textiles. ${ }^{10}$ This was followed by commerce and trade sector where women worked as secretaries, clerks, saleswomen or service personnel and finally in the professional and technical sector as teachers and nurses. ${ }^{11}$

Judging from the statistical data, the Singapore government's policies regarding the increase of the female labour force participation was a success. Since the 1970s the rate has been steadily increasing. Not only is there an increase in female labour force participation, the participation rate of married women in the labour force is also rising. This can be seen in Table 1. The General Household Survey 2005 reported that the growth rate of labour force participation was higher for females than males. ${ }^{12}$

Table 1 Labour Force Participation Rate in Singapore

\begin{tabular}{lccccc}
\hline & $\mathbf{1 9 7 0}$ & $\mathbf{1 9 8 0}$ & $\mathbf{1 9 9 0}$ & $\mathbf{2 0 0 0}$ & $\mathbf{2 0 1 0}$ \\
\hline Total labour force participation & 55.3 & 63.2 & 63.2 & 63.2 & 66.2 \\
Female labour force participation & $\mathbf{2 8 . 2}$ & $\mathbf{4 4 . 3}$ & $\mathbf{4 8 . 8}$ & $\mathbf{5 0 . 2}$ & $\mathbf{5 6 . 5}$ \\
Married women participation rate & 14.7 & 29.8 & 45.6 & 49.2 & 58.4 \\
\hline
\end{tabular}

Source: Department of Statistics Singapore - Time series on Labour Force Participation Rate, 2011 (http://www. singstat.gov.sg/stats/themes/economy/hist/labour.html), Report on Labour Force in Singapore (2010), Department of Statistics Singapore - Singapore Population (2001), Singapore Census of Population 1990 Economic Characteristics, Census of Population Singapore 1980 Economic Characteristics.

A breakdown according to ethnic groups shows that even though the Malay female labour force participation rate is lower than for other groups, nevertheless, Malay female labour force participation has been steadily increasing since 1970 (see Table 2). The 2000 figures show a decrease in the participation rate of both Malay and Indian women. However, the General Household Survey 2005 shows that while there are Malay women who are leaving the labour force after getting married, $46 \%$ continue to stay employed.

Table 2 Female Labour Force Participation Rates, by Ethnic Group

\begin{tabular}{lrrrr}
\hline & $\mathbf{1 9 7 0}$ & $\mathbf{1 9 8 0}$ & $\mathbf{1 9 9 0}$ & $\mathbf{2 0 0 0}$ \\
\hline Malay & 14.3 & 44.6 & 45.0 & 40.8 \\
Chinese & 27 & 44.5 & 49.4 & 52.0 \\
Indian & 16 & 44.1 & 50.9 & 46.9 \\
Others & 23.9 & 34.7 & 42.0 & 45.7 \\
\hline
\end{tabular}

Source: Statistics Singapore - Key stats (http://www.singstat.gov.sg) Census of Population 1980 Singapore Release No. 4 Economic Characteristics, Singapore Census of Population 1990 Economic Characteristics. 


\section{Trend Toward Dual-Income Couples}

The increase in the participation rate of married women in the labour force contributed to the trend toward dual-income couples. ${ }^{13}$ Over the last two decades the number of dual income couples in Singapore has been gradually increasing. Indeed by 1990 the number of dual career couples was $40 \%$ of the total married couples compared to $27 \%$ in $1980 .{ }^{14}$ In a labour force survey in Singapore it was found that the number of dual income households was $45 \%$ among married couples in $2001 .^{15}$

Taking a closer look at women's participation in the labour force, the rate of participation corresponds with the level of educational attainment of women. Women with tertiary education are the majority of female labour force in Singapore. ${ }^{16}$ There is a close relation between women's educational qualification and their participation in the labour force.

The increasing number of women in the labour force must also be seen in terms of occupational opportunities for women. The government's development strategy of import-substitution industrialisation since Singapore's independence in 1965 has indeed created opportunities for women to work. In its efforts to restructure Singapore's economy in the late 1970s the government's emphasis on human resource development has increased its demand for labour even more. Singapore's Economic Development Plan for the 1980s, announced in Parliament, conveyed the government's commitment to "optimise scarce manpower by encouraging more women $[\ldots]$ to work". ${ }^{17}$

The trend toward dual-income couples is also tied to rising standards of living. In a report of the national survey on married women in 1983, it was found that "about half of the married women indicated income as their main motive for working". ${ }^{18}$ Furthermore, as pointed out by Yuen and Lim, the extra income from working women allows families "to afford the many 'luxuries' which have become part and parcel of "modern living"" ${ }^{19}$ This has also been highlighted by Lee et al. ${ }^{20}$ Data from the Department of Statistics show that the income of working women "has boosted the financial situation of married couples". ${ }^{21}$ In addition, the average percentage of a woman's earnings to the dual-income has increased from $36 \%$ in 1980 to $41 \%$ in $1990 .{ }^{22}$

Women's contribution to the household income has become increasingly significant. ${ }^{23}$ It is thus important to note the combination of factors that explain the trend toward dual-income couples. Together with the push from the government for women to participate in the labour force and the increasing need for an extra income this new form of family structure comprised of working parents is increasingly familiar in the lives of Singaporeans. 


\section{Division of Labour in Dual Income Households}

\section{Division of Household Labour and Gender Equality}

Studies have shown that household work is women's work. ${ }^{24}$ As such when women have paid work through employment, they are doubly burdened in having to do their 'second shift' of having to see to household work. ${ }^{25}$ While studies show that men do carry out household and child-caring work, women still see to the bulk of household work. ${ }^{26}$

In this body of literature on household division of labour, there are also those who argue that there are couples who "shared it all", i.e. housework, childcare and financial responsibility. ${ }^{27}$ Goodnow and Bowes ${ }^{28}$ in their study of 50 couples from different socio-economic backgrounds in Sydney, Australia elaborated on how "sharing" is worked out. The findings of their study show that couples moved away from the conventional distinctions between 'men's work' and 'women's work' by dividing work on the basis of fairness, practicality or likes and dislikes.

These studies very often show that household and child-caring work is divided between wives and husbands (and sometimes children). There can be another solution, i.e. allocating tasks to yet another person such as a live-in helper. This option is available to couples in Singapore. This opens up questions as to whether such households are more or less equal.

\section{Division of Labour in Malay Households in Singapore}

In her ethnographic work on Malay households in Singapore in the late 1950s, Judith Djamour $^{29}$ described the clear division of responsibilities between women and men in Malay households. The head of the household is the chief wage earner and is usually a man. Women see to housework and caring for small children. Because of the lack of other studies on Malay households at that time Djamour's ethnography is indeed valuable and important in providing details of practices in Malay households. It nevertheless is vital to take note, as I have pointed out elsewhere, that Djamour's work tends "to subscribe to the notion of the ideal-type family or household" ${ }^{30}$

Studying Malays in Singapore, Tania $\mathrm{Li}^{31}$ outlined the principle by which a Malay household is managed. She pointed out that the husband's obligation is "to provide adequate food, housing and clothing for his wife" 32 and the wife's obligation is to "provide domestic services for her husband and children". ${ }^{33} \mathrm{Li}$, however, argued that there are internal negotiations. Nevertheless, her findings indicated the persistence of the principle that the Malay man has to provide financially for his wife and children and the Malay wife provides domestic services for her husband and children. So in cases where women are employed, they are seen to be going beyond their obligation. Furthermore, the idea of the husband's role to provide can be seen to operate in 
the household's budget where the husband's wage is used for "essentials" and the wife's income is used for items perceived as "supplementary". ${ }^{34}$

In her study, Li emphasised what she thought was the common situation, i.e. one in which the wife was not working and the husband was the sole wage earner. ${ }^{35}$ Given that Li herself noted that Malay women were not forgoing the opportunity to have employed work, there is a need to take into account what the practices of management in Malay dual-income households are and to ask if the principle which Li cited continues to operate in such households.

\section{Practices of Division of Labour in Malay Dual-Income Households}

My research on Malay dual-income households carried out between 2002 and 2006 looked at how young Malay couples manage child-caring as working parents. The use of the term 'young' here is derived from the study by Wong ${ }^{36}$ which divides family according to its life cycles - that is, beginning family, young family, mature family and ageing family. A young family is a nuclear family with young pre-primary and primary school children. Couples whose family life cycle is at the young stage face the need for childcare management and would need to work out the different tasks in child caring. A total of ten dual-income couples who are professionals were interviewed (see Appendix 1 for profile of couples). I conducted in-depth semistructured interviews. Each interview lasted between two to three hours. There were cases when follow-up interviews had to be conducted. While the focus was on child caring, the research also encompassed how working couples combine family and work in general. In the research household tasks include both caring for children and seeing to housework. The delineation between child-caring and housework tasks is crucial especially to discern Malay men's contribution to household tasks.

The biggest challenge in the research was the time factor. It was not easy to accommodate the work schedules and family time of both informants and me. Some of the interviews had to be conducted within sandwiched time during lunch hours or after work before returning home. The time constraints faced by dual income couples because of their work hours and family commitments is very evident.

Already at the beginning of my research I sensed that informants, both female and male, assume that women are responsible for child caring. This was reflected by an unwillingness of some male informants to be interviewed. These men explicitly said that their wives deal with anything to do with their children. Some of them agreed when I pressed to interview them while others were not keen to be interviewed. Five out of the ten men agreed to be interviewed (Couples E, F, H, I and J). Out of the five who did not want to be interviewed, one (Couple G) could not fit in time because of his tight work schedule. The wife of another (Couple B) decided that 
it would not be necessary for me to interview her husband. It was not possible to persuade the husbands of the remaining three (Couples A, C and D) for an interview.

\section{Distribution of Child-Caring by Young Malay Dual-Income Couples in Singapore}

The concern for working parents is how to combine family and work responsibilities. The most immediate dilemma for young dual-income couples is how to see to the caring of their young children while they are at work. I have dealt with the kinds of childcare arrangement options which young Malay dual-income couples decide on. ${ }^{37}$

In this article I emphasise how Malay working parents handle child-caring. Child caring involves many tasks. The child has to be bathed, dressed and fed for the babysitter, kindergarten or school. The child has to be brought to and from the child minder be it a member of the family or a childcare centre. There is need to put aside time for leisure with the child and for helping her/him to adjust and deal with kindergarten or school. When the child is sick, special attention and care must be given. In a family context of working mothers and fathers the caring for children has to be carefully thought over; requiring working out and carrying out tasks and always being prepared for the unexpected. One of my concerns in my research is how child-caring tasks are divided in Malay dual-income households.

\section{Allocating daily child-caring tasks}

In my interviews, informants were given a list of childcare tasks, which they could expand on. They were asked to indicate who carries out these daily tasks (see Appendix 2). The tasks include bathing, dressing, changing diapers, meal preparation, feeding, ferrying children, playing, reading, supervising homework, and putting children to sleep.

The kinds of task depend on the ages of the children. Thus for example babies and toddlers would need to be bathed, dressed, fed, have their diapers changed and put to sleep whereas schoolchildren would need supervision for their homework. Similarly the need to see to particular tasks varies with age. For couples with schoolchildren the frequency of ferrying their children to school and other school-related activities is very high. Some couples send their children to special classes or tuition and therefore ferrying children is again high.

Child-caring tasks in Malay dual-income households are divided between the couples sometimes shared out with their parents and in several cases allocated to live-in helpers. ${ }^{38}$

From the findings it is clear that in Malay dual-income households, wives carry out the bulk of the daily child-caring tasks particularly the preparation of meals. They rely on grandmothers and helpers to carry out some tasks such as bathing, dressing, changing diapers, meal preparation, feeding and playing. Other than ferrying the 
children men do not predominate in any of the other child-caring tasks. For these other tasks men share the workload with women.

\section{Seeing to unpredictable childcare demands and other special requirements}

Apart from the daily childcare tasks there are also childcare demands that are unpredictable. ${ }^{39}$ In particular when children are sick special attention and care may be required. The task demarcations include taking the child to the doctor, caring for the sick child and administering medication.

Who takes the child to the doctor depends on the seriousness of the child's illness. If the child's situation does not require the attention of doctors immediately, most couples would take their sick child to the doctor together. This is often after their working hours, i.e. in the evenings or on a weekend. In a situation where the child is very sick and needs to be seen by the doctor immediately, who takes the child to the doctor would depend on who has the most flexible work hours.

It's easier for me to call my office and tell them I have an emergency and need to take my daughter to the clinic. It's not so easy for my husband because of his class schedule. (Wife of Couple C)

Similarly in the case of Couple $\mathrm{H}$ where the husband has more flexibility at work:

It's easier for me to take off from work than my wife. Besides, I have the car. (Husband of Couple H)

Only one couple (Couple B) occasionally turns to the grandparents to take their sick child to the clinic. In this case the grandparents take care of the two children while the couple is at work.

Couples do not usually take leave from work to be with the sick child. They rely on their respective child minders to look after the sick child, i.e. grandmothers or maids. However in situations where the child is seriously ill some of the women took leave from work to be at home with the sick child (Couples C and G). These women take advantage of the five days unrecorded leave per year granted to female civil servants for each child below six years old. Only one man (Couple E) took leave from work to take his sick child to the clinic and stay home with his child. In this case his wife is not a civil servant. Both parents and child minders, depending on who is available at the time the child needs to take her/his medicine, share administering of medication to the sick child.

School holidays create a situation where schoolchildren will need to be taken care of during the time they would otherwise be in school. In my study there are six couples with schoolchildren. Very often the children will be taken care of by the respective child minders. However couples do make special arrangements for children to have activities during the school holidays. These special arrangements 
would involve extra ferrying of children or taking leave from work. As one woman relates:

My children get bored and that is when they start irritating each other. They will call me or my husband and start complaining. My husband and I will tell them what they can do for the day [...] but it is boring for them to be at home the whole day. Sometimes we take them to their cousins' house for them to spend the day or my sister will send her children over to our place [...] or they'll spend the day with their grandparents. This means that one of us will have to send them and pick them up. We take leave to go for a holiday together. The school holidays are long but I don't have that many leave days. Sometimes my husband takes the afternoon off from work when he doesn't have too much work. I try and make sure I come home early. (Wife of Couple $G$ )

Two other couples (Couples F and J) arrange for their children to take part in holiday programmes offered by private organisations or by schools. No ferrying is involved, as the children are old enough to take public transport:

My son is in the school band. The school has extra music practices during the school holidays because they are preparing for a music tour. We let him participate because he likes music and he has something to do during the holidays. Otherwise he will just be at home [...]. He goes to school by bus with a friend who lives nearby. It's not far [...] just a few bus stops. (Wife of Couple J)

Since the husband of Couple $\mathrm{C}$ is a school teacher, he is able to spend time with their two daughters during the school holidays. On the days when he has to be in school for a meeting, the live-in helper will look after the children. The wife will also take leave from work to spend time with the children during the school holidays.

Three out of four of the children of Couple D are old enough to organise their own programme during the school holidays. Nevertheless both husband and wife do take leave to go for a holiday with the children.

There appears to be more sharing out between husbands and wives for unpredictable childcare demands and special requirements during school holidays. The common point in the narrations of informants, both women and men, are the time constraints because work conditions require them to be present at the workplace and therefore they are prevented from being present at home when their children are sick or when they have school holidays.

\section{Division of Housework in Singapore Malay Dual-Income Households}

Six of the ten couples in my study have live-in helpers. ${ }^{40}$ The main reason for these couples to have a live-in helper is to have someone mind their young children while they are at work. The added advantage of having a live-in helper is that housework can be transferred to the helper. 
Except for cooking, all couples who have live-in helpers transfer most housework tasks to their live-in helpers. In the case of two couples (Couples C, F) the women do the cooking for dinner although the helpers will be asked to prepare the ingredients for the dishes. For these women, the reason is because they prefer their own cooking to the cooking of the helper. The wife of Couple $\mathrm{G}$ occasionally cooks and the wife of Couple C sometimes cooks on weekends.

There are differences in the practices of couples who do not have live-in helpers. The wife of Couple A sees to all the household tasks:

I do everything. It's manageable - we don't have a big flat. I get up early to do the washing and hanging up of the clothes. And mopping I do before I go to bed. And ironing, when I am back from work. He will look after our daughter when I am doing the housework. He helps [...] like changing the cushions and curtains for Hari Raya. (Wife of Couple A)

For Couples B, I and J there is some sharing of household tasks although the bulk is seen to by the women. The tasks which men tend to see to include vacuuming, cleaning the bathroom and toilet.

The housework task allocation in Couple I is based on whether the house space is seen to 'belong' to either of them. For example, the kitchen is the wife's space so she sees to the cleaning of the kitchen. There are two toilets in the apartment;one claimed by the wife, the other by the husband. They clean their respective toilets. Similarly they have their own work spaces and each is responsible to clean her/ his space. The cleaning of the shared spaces like the bedroom and living room is however the responsibility of the wife:

That's because she wants it in a certain way. (Husband of Couple I)

[...] Yah, I like it cleaned in a certain way [...] we just do it differently and I like it my way. (Wife of Couple I)

Going to market is one task which most couples share irrespective of whether they have live-in helpers or not. The sharing varies from couples going to the market together (Couple $\mathrm{B}, \mathrm{C}$ and $\mathrm{H}$ ) or the husband driving the wife to the market and waiting for her to complete the purchases (Couple A), or the wife sees to shopping in the wet market and the husband going to the supermarket (Couple G) or, the market shopping is done by whoever has the time (Couple E, F and I). The wife of Couple D sees to the shopping and the husband of Couple $\mathrm{J}$ sees to the shopping.

I have always done it [...]. I like to go to the market. Anyway she [wife] doesn't like to go to the market. (Husband of Couple J)

Housework is clearly a woman's responsibility in the Malay dual-income households of my study. In accordance with the findings of other studies on the contributions 
of women and men to household tasks, Malay women continue to do the bulk of the work even when they are employed. ${ }^{41}$

Living in Singapore allows for the hiring of live-in helpers - an option that is not always available in other countries. With a live-in helper household tasks which would have been done by women are transferred to another woman, i.e. the live-in helper. However, Malay women also see to training the live-in helper when they are newly employed. Those women in my study who have live-in helpers take charge in supervising their respective helpers with regards to the housework. If the work is not done satisfactorily, it is the woman who sees to it that the helper is told. As such, even when women are not directly carrying out housework tasks, they take full responsibility in ensuring that the tasks are carried out well by the respective helpers.

\section{Task-Sharing in Malay Dual-Income Households}

\section{Changing Practices}

From the preceding section we can notice some changes in the division of labour in Malay dual-income households. While Malay women are managers of the household and continue to be responsible for the bulk of household work, there are changes in Malay women's practices of managing household work. This is especially so for women who have live-in helpers. Although some women had reservations about transferring the task of cooking to their helpers, most no longer directly perform the housework tasks. Clearly, the women in my study with live-in helpers have no problems transferring housework tasks to live-in helpers despite some women's occasional dissatisfaction with the quality of performance of their helpers. This is somewhat contrary to the findings of Inserto who found that even though the majority of the women in her study had live-in helpers, they relied on the helpers only to see to the cleaning of the house, doing the laundry and minimal cooking. ${ }^{42}$ Inserto also pointed out that the women in her study had anxieties about losing their spouses because of "perceived role changes". ${ }^{3}$

The women in my study were more selective when transferring child-caring tasks to helpers. Women rarely transfer child-caring tasks to helpers when they are at home. They would rather do these tasks themselves while the live-in helpers are made to carry out housework tasks. Some of the women feel that transferring tasks to live-in helpers gives them 'quality time' with the children:

My maid prepares dinner so when I come home I have some time with my children before dinner. I take them to the playground or the swimming pool at our place. (Wife of Couple $G$ ) 
There are specific tasks which the women think their helpers are not capable of. This includes spending playtime with children or reading to children. Live-in helpers are delegated all other child-caring tasks. As such, the women in my study do not have uncertainties about transferring most of the child-caring tasks to their helpers unlike the women in Inserto's study. ${ }^{44}$

Women are turning to their husbands to assist them. As pointed out, the delegation of housework tasks to men depends on whether or not couples have live-in helpers. In the absence of live-in helpers women rely on husbands to see to some housework tasks. However, even with helpers they do depend on their husbands for assistance in some child-caring tasks.

Malay fathers, like their counterparts in America ${ }^{45}$ and Britain,${ }^{46}$ do carry out some child-caring tasks. Nevertheless, the Malay men in my study mostly perform these tasks as helpers, i.e. taking instructions from their wives. This applies even to the task of ferrying children which the Malay men in my study predominantly carry out. Brannen and Moss, in their study on constraints that women in Britain face in combining employed work and motherhood, found that the men also carry out tasks "in the role of assistant, helping out with children [...] rather than the role of equal participant" ${ }^{47}$ In his study on American men's involvement in family work, Coltrane also found that men are generally "helper husbands". ${ }^{48}$

There are differences in the amount of Malay men's contributions to housework. Men in households with live-in helpers do less housework tasks than those men in households without live-in helpers. While the decision to hire live-in helpers is to mind young children while parents are at work, helpers are made to do the bulk of housework tasks. There is therefore no change for the men in such households where housework division of labour is concerned. However, men in households without live-in helpers are helping out in some housework tasks.

Indeed findings from my study show that there are small changes taking place in Malay dual-income households. There is some sharing of child-caring and housework tasks between husbands and wives of the households. All men in my study do carry out some household work. This echoes the study by Coltrane and Adams ${ }^{49}$ who found that men in dual-income households in America participate in both child-caring and housework tasks.

Like Sullivan ${ }^{50}$ I stress the importance of recognising such small changes. There has indeed been a transformation within Malay households when we look back to earlier studies on household division of labour which show that there was hardly sharing of household work between Malay women and men. ${ }^{51}$

\section{Determinants for Sharing Household Work}

The sharing of household work, however, cannot be assumed. Taking a closer look at the nuances of the sharing of household work, there are factors which determine 
when sharing occurs between husbands and wives. Here, it is significant to note that Malay women are managers of the household. As managers they are the ones who decide what tasks are to be delegated to someone else as well as to whom the tasks should be delegated to.

\section{Women's time constraints}

Clearly employed women cannot fully see to all household tasks because of their work responsibilities. The normal eight working hours, not inclusive of travel time to and from work, means that mothers need to manage their time.

Not having enough time is a concern shared by the mothers in my study. They say that they "do not have enough time" (tak ada masa) for the tasks they have to do. But it is only when the time constraint is acute that women will transfer tasks. Prior to having a live-in helper Couple E had to share out the housework task:

Both of us had to do the housework [...] we come home late. I can't do everything on my own. I clean the house. He ironed the clothes. (Wife of Couple E)

Weekends [...], sometimes at night [...]. (Husband of Couple E)

Women also transfer child-caring tasks to their husband:

It's always a rush in the mornings. The maid will see to breakfast. The children will have to be woken up. I will wake the older children. My husband will wake our youngest up and get him ready. I can't do everything. I need help. The children won't be ready on time for the school bus [...]. (Wife of Couple G)

Sometimes I ask my husband to take them to the doctor when they are sick especially when I have to work on Saturday and he doesn't. I tell him [...] how can I go? I have to work so he has to take them. (Wife of Couple D)

Time constraints faced by women are clearly a result of work demands where women have very little space to negotiate their time. Their concern here is that someone else other than them has to see to the task.

\section{Notions of skills in carrying out tasks}

Women say that they transfer tasks according to the ability (or inability) of the husband:

I prepare the dinner while my husband minds the children. It's not that he can't cook. He can cook [...] simple dishes. But he takes too long. I can cook better and faster than him. (Wife of Couple C) 
My husband doesn't bathe her [daughter] or change nappies. He cannot do these things $[\ldots]$, he doesn't know [...], he's not used to doing this [tak biasa]. So I do everything. (Wife of Couple A)

This also applies to housework tasks:

I don't expect my husband to do housework. It's not saying anything bad about him. He can do other things but housework [...]. I don't think he can. (Wife of Couple D)

Goodnow and Bowes ${ }^{52}$ highlighted competence of partners as a contributing but not a decisive factor for sharing out household work. The couples in their study say that competence is not a 'real reason' and may be challenged..$^{53}$ The narrations above show some women excusing their husband for incompetence or setting their standards to judge their respective husbands' level of competence. However, not all women in my study excuse or judge their husband's skills in carrying out household work. Interestingly husbands of those who do, tend to refuse to be interviewed.

\section{Availability of partners to carry out tasks}

Some couples declared that their particular allocation of child-caring tasks is for practical reasons. The partners' work schedules or other responsibilities either make them available or not available to carry out child-caring tasks. The husband of a couple did say that he actually could cook better than his wife. His wife agrees but he still does not see to daily meal preparation:

He [husband] can cook very well [...] better than me. If we invite family and friends he will cook but he doesn't cook every day. No time [...] he's so busy. He has to visit his sick father every evening after work. So I cook. (Wife of Couple E)

In the case of Couple $\mathrm{J}$, for example, the wife sees to the caring needs of their son because she works from home whereas her husband is away at work. Differing as well as flexible working hours of couples also means that a task has to be assigned to the partner who is available.

He [husband] starts work very early and his working hours are fixed whereas mine are flexible and erratic sometimes. I can go in late but I also get back home late. So I get the children ready, give them breakfast and take them to the childcare centre by taxi. He has the car and picks them up from the centre and sees to their dinner. Sometimes he will pick me up from work and we'll go out for dinner. (Wife of Couple I)

Similarly when a partner is not available because of long working hours then the other has to see to the child-caring tasks. There were two couples (F, G) where the male partners have longer working hours and therefore their wives carry out child-caring tasks or allocate them to live-in helpers: 
$\mathrm{He}$ [husband] comes home late because he has meetings with clients. So, most of the time I spend the evenings with the children. He is just not there. (Wife of Couple G)

That men are less available for child-caring and housework tasks because they work longer hours is familiar in the literature. ${ }^{54}$ Availability as a factor affecting the way in which household tasks are arranged has also been pointed out by Goodnow and Bowes. ${ }^{55}$

\section{Malay Women and Maternal Gate-Keeping}

In their study of women from dual-income households in America, Allen and Hawkins ${ }^{56}$ argue that "maternal gatekeeping", i.e. the idea that only women can see to certain tasks in the household, inhibits greater involvement of men in household and child-caring work. Allen and Hawkins outlined three dimensions of maternal gate-keeping: "mothers' reluctance to relinquish responsibility over family matters by setting rigid standards, external validation of a mothering identity, and differentiated conceptions of family roles". ${ }^{57}$

My study provides findings that there are Malay women who 'gate-keep'. This is exemplified in the way that Malay women as managers of households, decide what tasks husbands can or cannot do. To this extent, very much depends on what she defines as women's work and men's work. Women in my study determine the ability or inability, efficiency or inefficiency of their husbands in performing household and child-caring tasks and decide whether or not a task should be assigned to their respective husbands. While all the women with live-in helpers express the need to train their helpers (especially the new ones), none have expressed the need to teach their husbands skills to carry out tasks. It is also important to note that the men, who were willing to be interviewed, do not refuse the tasks that are allocated to them by their wives. It appears that Malay women's maternal gate-keeping is excluding more opportunities for collaborative arrangements for family work.

I would however exercise some caution in that gate-keeping is not restricted to mothers. Fathers too can carry out paternal gate-keeping in various domains pertaining to roles within family life. One indication of this is the way that most of the men in my study very often initially questioned the necessity to be interviewed in this study because "child caring is my wife's department". As pointed out by Coltrane, ${ }^{58}$ the belief of separate spheres and distinct roles for mothers and fathers are not confined to women alone. He argues that men's willingness to be involved in family work is very much tied with their view about women's and men's roles.

\section{Views on Gendered Roles - Beyond Households}

Views about gendered roles are not confined to the households. In this section of the article, I show the prevalence of the view of gendered roles outside of the households. 
My concern here is with regards to "maternal identity confirmation" which Allen and Hawkins $^{59}$ delineate as a dimension of gate-keeping. They emphasise "the impact that the internalisation of cultural expectations of mothering has on attitudes about maternal and paternal involvement in family work" ${ }^{60}$ In this regard, I demonstrate the occurrence of such external validation in the Singapore context. I first of all look at Malay cultural expectations of "the ideal Malay woman". I then present the discourse of the 'supermom' to show the Singapore government's expectations of woman's role as mother.

\section{Singapore Malay Cultural Perceptions of Roles of Women and Men}

To reiterate, studies by $\mathrm{Li}_{1}{ }^{61}$ Zarinah $^{62}$ and Inserto ${ }^{63}$ indicate that there are prevailing Malay cultural perceptions regarding roles of women and men. In her study on how Malay women manage their multiple roles as worker, mother and wife Inserto points out that while the preference of the women in her study is for an egalitarian relationship whereby husbands will help out, there is nevertheless an underlying view that "the husband's main responsibility is to provide for the family, and the wife's duty is to take care of the family". ${ }^{64}$

Such perceptions are reproduced in different sites. Nurhaizatul for example critically analysed portrayals of Malay women in the Berita Harian, the local Malay newspaper. Covering the period between the 1970s and 2009 she uncovered the constructions of "the ideal Malay woman" that among others include articles which reminded Malay women of her "important duty" to "organise the household effectively". ${ }^{65}$

Indeed within the context of Malay women's increasing involvement in the labour market, their roles as mothers and wives become crucial elements in which these perceptions of gendered roles surface. This is visible is public talks on topics pertaining to the family organised by Malay organisations and mosques. ${ }^{66}$ The emphasis in these talks is always on the gendered role of men and women, i.e. the responsibility of the father is to provide and the responsibility of the mother is to take care of children. An example can be seen in a public forum organised by the Malay Activity Executive Community (MAEC) of the Clementi Community Centre on the theme of 'Harmonious Family' (Keluarga Harmoni) in September 2003. Local and regional religious experts were invited to talk at the forum. In this forum both speakers are of the opinion that a harmonious family is achieved when all family members perform their respective roles accordingly. The role of the father is to provide and lead while the role of the mother is expressed in terms of the mother's responsibility to give love and care (beri kasih sayang). Citing verses from the Qur'ân these religious experts reiterate that such roles are backed by the tenets of Islam. In a Friday prayers sermon, ${ }^{67}$ the Muslim congregation is reminded that "[h]usbands have a heavy responsibility. He is a leader. He is responsible for 
leading the family, for controlling it and for protecting each member in it. [...] Wives also have a role to play. They give birth to a new generation of Muslims. They raise children who contribute to the community." That expectations of Malay women's role are very much informed by religion is clearly illustrated by Nurhaizatul's study on Singapore Malay women's embodied agency. She showed how duties of a mother and wife are perceived as religious contributions (Arab. 'ibādah). As such, all household tasks are acts of piety. ${ }^{68}$

Malay organisations also repeat the perceptions of gendered roles of Malay women and men. This is discernible in the efforts of MUIS (Majlis Ugama Islam Singapura) or the Islamic Religious Council of Singapore to remind Muslim parents of their responsibilities. In August 2000, MUIS launched its Family Development Department TAQWA Family Values campaign following the recommendations made by the Muslim Divorce Committee to look into rising divorce rates. Focusing on the need to build "strong and cohesive families", the campaign carried out talks promoting the idea of TAQWA family. An aspect of such a family is the need for parents to fulfil their responsibilities (tanggung jawab) as fathers and mothers - i.e. to see to the provisions to children and to see to caring for children, respectively.

Such views recur in marriage preparation courses which Malay couples have to attend prior to solemnising their marriage. These courses are offered by private companies that are endorsed by the Registry of Muslim Marriages in Singapore. Stretching over two days the course prepares couples with "the knowledge and skills for marriage, financial management, relation communication skills and managing the responsibilities, pressures and expectations of married life" ${ }^{69}$ Bersama $\mathrm{Mu}$ (Together with you) Marriage Preparation Course for example offers couples an interactive 14-hour session designed by marriage counsellors. A range of topics are covered including roles and responsibilities of husband and wife. Shared responsibilities are discussed. However the underlying understanding remains of the provider role of the men and the care giver role of the women.

It can be seen that existing Malay cultural expectations of women's role predominantly stress appropriate behaviour of mothers as care givers. Indeed, from the narrations of the women in my study, Malay women who are employed do not willingly relinquish care-giving tasks. These women refer to these normative guidelines that spell how they should behave. It can be inferred that while the Malay women in my study are increasingly pursuing education and career their role as mothers remain vital to them.

\section{The Discourse on the 'Supermom': The Government's Perceptions on the Woman's Role as Mother}

In the earlier efforts to promote women to participate in the work force, it was assumed that women would continue to fulfil their role as wives and mothers. How 
this role is to be fulfilled was very much left to individual women to work out. So while the government wants a change of attitude and to "break barriers that keep women at home" it has left it to the woman "to choose her role". ${ }^{70}$

The kinds of answers that women gave when they chose to work reflected the tie between the roles of women as mothers. Wong points out that women turned to "the services of close kin and relatives living in the same household" but when these services were not available women "schedule their work activities in such a manner as to enable them to shoulder the burden of childcare and other household duties at the same time". ${ }^{71}$ Women were expected to take up the dual roles of mother and employee and see to mothering and work responsibilities. It was not until trends showing that women stopped work when they married and had children that the government began to concern itself with provisions for child-caring services. ${ }^{72}$ In this section I present the discourse on the 'supermom' and thereby tease out the Singapore government's perceptions on woman's role as mother.

The attempts by the government to entice women to join and stay in the work force via a number of incentives and provisions since the early 1980s opened up debates in various directions pertaining to employment conditions and gender inequalities at work, woman's employment and child development as well as the suitable minding arrangements for children. These debates unveil the very notion of woman's role as mother. As such, when she is employed she therefore has to somehow juggle responsibilities at work and in the family.

In line with its need for female labour force participation the image of the "working mother" became a prominent feature. The positive outcome of employment for women and children became an argument and that "a woman can be a better mother if she is also a good worker" ${ }^{73}$ Anticipating guilt conscience and concern about the mother-child relationship, experts in the form of psychologists, educationists and family counsellors provided assurance that "the ill effects of maternal employment are not always evident". ${ }^{74}$ Advice to women who were feeling guilty came from female readers of the local newspaper. The letters pointed to quality childcare in terms of time management: "efficiently using whatever time she is able to spend with the child" or "The mother can indeed organise her time efficiently, in accordance to the maturity of the child." 75

Indeed to be good mothers women must "know how to divide your time". ${ }^{76}$ In the local newspaper, stories of how women juggle family and work are presented. The answers range from having a husband who cooperates and does his share of housework to making child-minding arrangements, to juggling a full time career and managing family with a live-in helper. ${ }^{77}$ These stories end with a note of how "career and motherhood need not be mutually exclusive" $" 78$ and that women must learn how to do a "balancing act." ${ }^{" 79}$ Being a mother therefore is the ability to 
balance family and work. When women are able to do this they become 'quality mums' or 'supermoms'. ${ }^{80}$

The government is not unaware that married women who decide to continue to work are facing problems in managing this 'balancing act'. Part of the problem is in the home. As a study by the Singapore Council of Women's Organisations found, "there was hardly any difference in the amount of housework done by the woman who goes out to work and one who stays at home" ${ }^{81}$ That a coordinated national policy was needed to help women play "dual roles of being a mother and a working person" was spelled out. ${ }^{82}$ This need was later reiterated at a United Nations forum on women in terms of improving women's lives. ${ }^{83}$ The answers are formulated in terms of subsidy provisions and increasing numbers of childcare centres as well as improving their quality. This reinforces the government's push for women to be employed and for childcare centres as substitutes while mothers are at work.

Voices that called for men to change their attitudes and contribute to domestic chores and child caring did surface in the parliament, in letters from the public, as well as through support of a woman's non-government organisation, AWARE. ${ }^{84}$ This call was reiterated as a national survey found that "husbands are chief cause of problem" ${ }^{85}$

Over the following decades the government's stand continued to push women to balance family and work but while the emphasis in the 1970s and 1980s was to shift the weight from the family to employment, the emphasis from the 1990s was to push the weight to family:

Working women need to strike a balance between their career goals and family responsibilities so as not to neglect their children, especially when they are young, said Labour Minister Lee Boon Yang yesterday. ${ }^{86}$

While the idea of 'part time motherhood' of the 1980s lingers on, women are now asked to spend more time with their children. ${ }^{87}$ There were calls that more help is needed for "working mums". ${ }^{88}$ Nevertheless what prevails is the image of the 'supermom' who succeeds in climbing up the career ladder and being 'number one person' to her children. ${ }^{89}$

Even as the government recognises the need to help parents have a "work-life balance" ${ }^{90}$ through its Marriage and Parenthood Packages of 2001, 2004 and 2008, these packages are based on the assumption that child caring remains to be the responsibility of women. This can be seen for example, in the number of leave days apportioned to mothers and fathers. Women have 16 weeks as compared to three to six days of paternity leave. Official responses to questions as to why paternity leave is still minimal were quick to cite studies from Scandinavian countries which show that "most men don't take paternity leave." ${ }^{91}$ Interestingly findings from a survey 
conducted by AWARE on parenting leave in Singapore show that when paternity leave is available $75 \%$ of the men in their study utilise it.

More recently, in his Chinese New Year Message in February 2010 Prime Minister Lee Hsien Loong expressed his hopes that fathers will help working women to balance work and family:

Husbands can do many things to help their wives look after the children, including changing the nappies $[\ldots] .92$

Here, while the dual roles of women are taken for granted the dual roles of men as employees and fathers did not surface. Statements pertain to men having to assist. To this extent, what is being re-produced is women's role as mothers despite being involved in employed work and men's primary role remains as economic provider.

\section{Conclusions and Recommendations}

What emerges from the findings of my study is that:

- there are changing practices in contemporary Malay dual-income households in Singapore in terms of household and child-caring tasks.

- However, there are unchanging perceptions pertaining to notions of women's and men's work such that there is unequal distribution of labour. It seems that Malay women's maternal gate-keeping limits the Malay men's involvement in household and child-caring work.

- As I have also indicated, men's paternal 'gate-keeping', although not the focus of my study, can also act as barriers toward a more equal division of household labour. These gendered notions of family work, however, are not confined to Malay women and men in the household.

- I have demonstrated that there are existing Malay cultural expectations as well as the Singapore government's perceptions that validate gendered division of labour in the household.

- It is therefore imperative to take into account these normative guidelines of appropriate gender behaviour in an attempt to explain the persistence of an unequal division of labour.

\section{Notes}

1. Maila Stivens, "Post-Modern Motherhoods and Cultural Contest in Malaysia and Singapore", in: Theresa Devasahayam and Brenda S.A. Yeoh (eds), Working and Mothering in Asia: Images, Ideologies and Identities (Singapore: National University of Singapore Press, 2007), 29-50; Mina Roces and Louisa Edwards, Women in Asia (Critical Concepts in Asian Studies), 4 vols (London: Routledge, 2009), vol. 1. 
2. Singapore Department of Statistics, General Household Survey 2005 (Singapore: Department of Statistics, 2006).

3. Arlie Hochschild, The Second Shift: Working Parents and the Revolution at Home (New York: Viking Penguin Inc., 1989); Beth Anne Shelton, Women, Men and Time: Gender Differences in Paid Work, Housework and Leisure (New York: Greenwood Press, 1992); Jacqueline J. Goodnow and Jennifer M. Bowes, Men, Women and Household Work (Melbourne: Oxford University Press, 1994); Julia Brannen and Peter Moss, Managing Mothers: Dual Earner Households after Maternity Leave (London: Unwin Hyman, 1991); Hester van der Vinne and Monique Mascha Brink, "Dilemma or Compromise: The Division of Housework and Child Care Among Dual Earners", in: Gerard Frinking and Tineke Willemsen (eds), Dilemmas of Modern Family Life (Amsterdam: Thesis Publishers, 1997), 91-111; Sabine Walper and Nancy L. Galambos, "Employed Mothers in Germany", in: Judith Frankel (ed.), Families of Employed Mothers: An International Perspective (New York and London: Garlan Publishing Inc., 1997), 35-65.

4. Suriani Suratman, "Old Problems, New Strategies? Childcare Management in Malay Dual-Income Families in Singapore", paper presented at the Southeast Asian Association for Gender Studies, Malaysia Branch (SAMA) Conference on "Women and Men in Changing Societies", Bangi (Malaysia), 14-15 September 2002.

5. Eadem, "Looking for Help: Organising Childcaring by Employed Women in Singapore", paper presented at the "Workshop on Women as Workers, Mothers and Caregivers: Coping with Changes, Challenges and Commitments", Singapore, 18 January 2003.

6. Eadem, "He Has a Career - So Does She! Changing Gender Relations in Singapore Malay Dual Income Households?" paper presented at the International Conference on Malay Culture and Society, Universiti Brunei Darussalam, Brunei, 3-6 November 2009.

7. Sarah M. Allen and Alan J. Hawkins, "Maternal Gatekeeping: Mothers' Beliefs and Behaviours That Inhibit Greater Father Involvement in Family Work", Journal of Marriage and Family 61, no. 1 (1999), 199-212.

8. Aline K. Wong, Women in Modern Singapore (Singapore: University Education Press, 1975), 31.

9. See ibid., 31, for the Prime Minister's remark in his appeal to the Singapore Employer's Federation.

10. Lai Ah Eng and Yeoh Lam Keong, Economic Restructuring, Female Labour Participation and Female Skills Formation in Singapore: 1976-1984 (Singapore: Asian Pacific Development Centre, 1984); Jean Lee, Kathleen Campbell and Audrey Chia, The Three Paradoxes: Working Women in Singapore (Singapore: Association of Women for Action and Research, 1999).

11. Lee, Campbell and Chia, The Three Paradoxes, 14.

12. Singapore Department of Statistics, General Household Survey 2005, 21.

13. I use the term dual-income couples and not dual-career couples in a similar manner as Lewis et al. have used the term dual-earner family. Dual-earner family applies to all families in which both spouses are employed. Dual-career families refer to "more elite groups of middle-class couples in high-status occupations with an opportunity structure, who may or may not be more highly committed to their jobs than the dual-earners" (Suzan Lewis, Dafna N. Izraeli and Helen Hootsmans, Dual-Earner Families: International Perspectives (London: Sage Publications, 1992), 3.

14. Singapore Department of Statistics, "Dual-Career Couples in Singapore", Occasional Paper on Social Statistics (Singapore: Department of Statistics, 1994), 3.

15. Ministry of Manpower, Report on Labour Force in Singapore, 2001 (Singapore: Manpower Research and Statistics Department, 2001), 3.

16. Ibid.

17. Suzanne Goldberg, "Mixed Messages: Public Policy and Women in Singapore", Commentary 7, nos 2-3 (1987), 26.

18. Ministry of Social Affairs, Public Forum 'Married Women in the Workforce', Organised by the Ministry of Social Affairs on 25 November 1983, Regional English Language Centre, Singapore (Singapore: Ministry of Social Affairs, 1983).

19. E.C. Yuen and V. Lim, "Dual-Earner Families in Singapore: Issues and Challenges", in: Lewis, Izraeli and Hootsmans, Dual-Earner Families, 64. 
20. Lee, Campbell and Chia, The Three Paradoxes.

21. Singapore Department of Statistics, "Dual-Career Couples in Singapore", 9.

22. Ibid., 10 .

23. Such a case is also found in other Asian countries for example, India where "two incomes are essential for the vast majority of the middle class wishing to maintain a comfortable standard of living (Uma Sekaran, "Middle-Class Dual-Earner Families and their Support Systems in Urban India", in: Lewis, Izraeli and Hootsmans, Dual-Earner Families, 47). In other cases such as in Sweden, the contribution of a woman's income is crucial where "two incomes are necessary to remain above the poverty line" (Karin Sandqvist, "Sweden's Sex-Role Scheme and Commitment to Gender Equality", in: Lewis, Izraeli and Hootsmans, Dual-Earner Families, 83).

24. E.g. Ann Oakley, Housewife (London: Allen Lane, 1974); Hochschild, The Second Shift.

25. Hochschild, The Second Shift; Suzanne M. Bianchi, "Setting the Stage: Work and Family Lives of Americans", in: Eileen Appelbaum (ed.), Balancing Acts: Easing the Burdens and Improving the Options for Working Families. A Conference Volume (Washington DC: Economic Policy Institute, 2000), 13-24.

26. Hochschild, The Second Shift; Brannen and Moss, Managing Mothers.

27. Linda Haas, "Determinants of Role-Sharing Behaviour: A Study of Egalitarian Couples", Sex Roles 8 (1982), 747-60; Gayle Kimball, 50-50 Parenting: Sharing Family Rewards and Responsibilities (Toronto: Lexington Books, 1988).

28. Goodnow and Bowes, Men.

29. Judith Djamour, Malay Kinship and Marriage in Singapore (London: Athlone Press, 1959).

30. Suriani Suratman, "Studies on Malay Families and Households in Singapore: A Critical Assessment", NUS Seminar Papers No.35 (2002) [National University of Singapore, Department of Malay Studies].

31. Tania Li, Malays in Singapore: Culture. Economy and Ideology (New York and Singapore: Oxford University Press, 1989).

32. Ibid., 18.

33. Ibid., 19.

34. Ibid., 18.

35. Ibid., 20 .

36. Aline Wong, "Sex Roles, Lifecycle Stages, Social Networks and Community Development in Singapore", in: Shirley Ardener (ed.), Persons and Powers of Women in Diverse Cultures: Essays in Commemoration of Audrey I. Richards, Phyllis Kaberry and Barbara E. Ward (New York: Berg Publishers Limited, 1992).

37. Suriani Suratman, "Working Out Child Care Arrangements: Case Studies on Malay Dual Income Couples in Singapore", paper presented at the 5th Asia Pacific Sociological Association Conference “Asia Pacific Societies: Contrasts, Challenges and Crises", Queensland University of Technology, Brisbane, Australia, 4-7 July 2002.

38. Eadem, "Old Problems".

39. Eadem, "Looking for Help".

40. Eadem, "He Has a Career". Couples C, D, E, F, G and H have live-in helpers (see Appendix 1).

41. Brannen and Moss, Managing Mothers; Scott Coltrane, Family Man: Fatherhood, Housework and Gender Equity (New York, Oxford: Oxford University Press, 1996).

42. Fathiah Edrus Inserto, Choice, Social Structure and Serendipity: A Study of Multiple Roles Among 20 Malay Women in Singapore (Ann Arbor MI: University Microfilms International, 1997), 116.

43. Ibid., 136.

44. Ibid., 135.

45. Coltrane, Family Man.

46. Brannen and Moss, Managing Mothers.

47. Ibid., 191.

48. Coltrane, Family Man, 74 . 
49. Idem and Michele Adams, "Men's Family Work: Child-Centered Fathering and the Sharing of Domestic Labour", in: Rosanna Hertz and Nancy L. Marshall (eds), Working Families: The Transformation of the American Home (Berkeley CA: University of California Press, 2001).

50. Oriel Sullivan, Changing Gender Relations, Changing Families: Tracing the Pace of Change over Time (Oxford: Rowman and Littlefield Publishers Inc., 2006).

51. Djamour, Malay Kinship; Li, Malays.

52. Goodnow and Bowes, Men.

53. Ibid., 144.

54. E.g. Brannen and Moss, Managing Mothers; Shelton, Women.

55. Goodnow and Bowes, Men.

56. Allen and Hawkins, "Maternal Gatekeeping".

57. Ibid., 199.

58. Coltrane, Family Man.

59. Allen and Hawkins, "Maternal Gatekeeping".

60. Ibid., 204.

61. Li, Malays.

62. Zarinah Mohamed, "Parenting in Singapore: Father's Attitudes Towards Involvement in Childcare", academic exercise, National University of Singapore, Department of Sociology, 1990.

63. Inserto, Choice.

64. Ibid., 137.

65. Nurhaizatul Jamila Jamil, "Perempuan, Isteri, dan ... Embodied Agency and the Malay Women of Contemporary Singapore", MA thesis, National University of Singapore, Department of Sociology, 2009. 20-1.

66. As part of my study, I attended talks organised by Malay organisations as well as mosques on topics related to the family.

67. MUIS, 27 July 2001.

68. Nurhaizatul, "Perempuan", 50.

69. Registry of Muslim Marriages 2011.

70. The Straits Times [Singapore], 2 March 1980, "Break Barriers that Keep Women at Home, Says Mattar".

71. Aline Wong, Working Mother and the Care of Pre-School Children in Singapore: A Research Report for the Singapore Girl Guides Association (Singapore: The Singapore Girl Guides Association, 1981), 42.

72. Stella R. Quah, Family in Singapore: Sociological Perspectives (Singapore: Times Academic Press, 1998, 2nd ed.), 128, too points out that "[a]s the evidence on withdrawal from the labour force underscores the importance of motivating women to get a job and to remain working, policy planners felt that the most "important issue is the availability of childcare facilities"'.

73. The Straits Times [Singapore], 26 February 1984, "Good Worker = Better Mum. Eight Women Say Career Does not Mar Role as Mothers."

74. The Straits Times [Singapore], 3 July 1985, "When Mothers Go to Work ..."

75. The Straits Times [Singapore], 8 October 1984, "Working Mothers Can Get Rid of Feeling of Guilt"; and The Straits Times [Singapore], 23 October 1984, "Working Women and Bringing up Children. Part-Time Work is the Real Answer".

76. The Straits Times [Singapore], "Good Worker".

77. The Straits Times [Singapore], 5 April 1982, "Fostering"; The Straits Times [Singapore], 22 February 1982, "A Quiet Revolution"; and The Straits Times [Singapore], 19 April 1982, "Time Tussle".

78. Ministry of Social Affairs, Public Forum, 9.

79. The Straits Times [Singapore], 30 March 1984, "Balancing Work", The Straits Times [Singapore], 7 November 1987, "Mum Who Wants to Carry on Working: Fitting in Job and Family is a Fine Balancing Act"; and The Straits Times [Singapore], 30 September 1996, "Women Urged to 'Strike Balance"”. 
80. The Straits Times [Singapore], 12 May 1985, "Dhana Supports 'Quality Time' Mums"; The Straits Times [Singapore], 9 May 1986, “'Supermom' Who's Working Smart”; The Straits Times [Singapore], 18 September 2000, "Supermoms"; The Sunday Times [Singapore], 18 January 2004, "Supermom".

81. The Straits Times [Singapore], 8 March 1989, “'Housewives Cannot Be Nudged Back into Job Market'. Survey: Hardly Any Incentive for Them to Return to Work".

82. The Straits Times [Singapore], 2 January 1988, "Help Career Mums Play Dual Role - Coordinated National Policy Needed, Says MP".

83. The Sunday Times [Singapore], 11 June 2000, "More Help for Working Mum Says Yu-Foo".

84. The Straits Times [Singapore], 24 November 1983, "From Mum to Dad: Help Do the Chores"; The Straits Times [Singapore], 17 January 1989, "Call to Help the Working Mum in Other Ways"; The Straits Times [Singapore], 12 January 1980, "Sharing Domestic Chores 'Can Ease Burden on Wives"”; The Straits Times [Singapore], 2 October 1984, "It's About Time the Men did Something ..."; The Straits Times [Singapore], 2 January 1988, "Working Mothers Torn between the Demands of Home and Workplace"; The Straits Times [Singapore],14 November 1987, "Making Life a Little Easier for Our Working Mothers"; The Straits Times [Singapore], 30 January 1989, “Aware Backs Lobby by Working Mothers. Childcare Facilities Inadequate, Says Women's Group".

85. The Straits Times [Singapore], 2 October 1996, "Stressed Out? It's Worst for Working Women".

86. The Straits Times [Singapore], 30 September 1996, "Women Urged to 'Strike Balance"".

87. The Straits Times [Singapore], 3 and 4 February 1996, "Mums Who Work from Home".

88. The Straits Times [Singapore], 11 June 2000, "More Help for Working Mums, says Yu-Foo", and The Straits Times [Singapore], 15 November 2000, "Make Bold Moves for the Family, Urge MPs".

89. The Straits Times [Singapore], 23 September 2000, "Fine Balance to Have It All - Kids and Career".

90. Prime Minister National Day Rally Speech 2008.

91. The Straits Times [Singapore], 3 September 2004, “Bringing Up Baby: Why Dads Can't Be Left Out", and The Straits Times [Singapore], 20 August 2008, "More Tax Breaks, Parental Leave to Boost Singapore's Birth Rate".

92. The Straits Times [Singapore], 15 February 2010. 


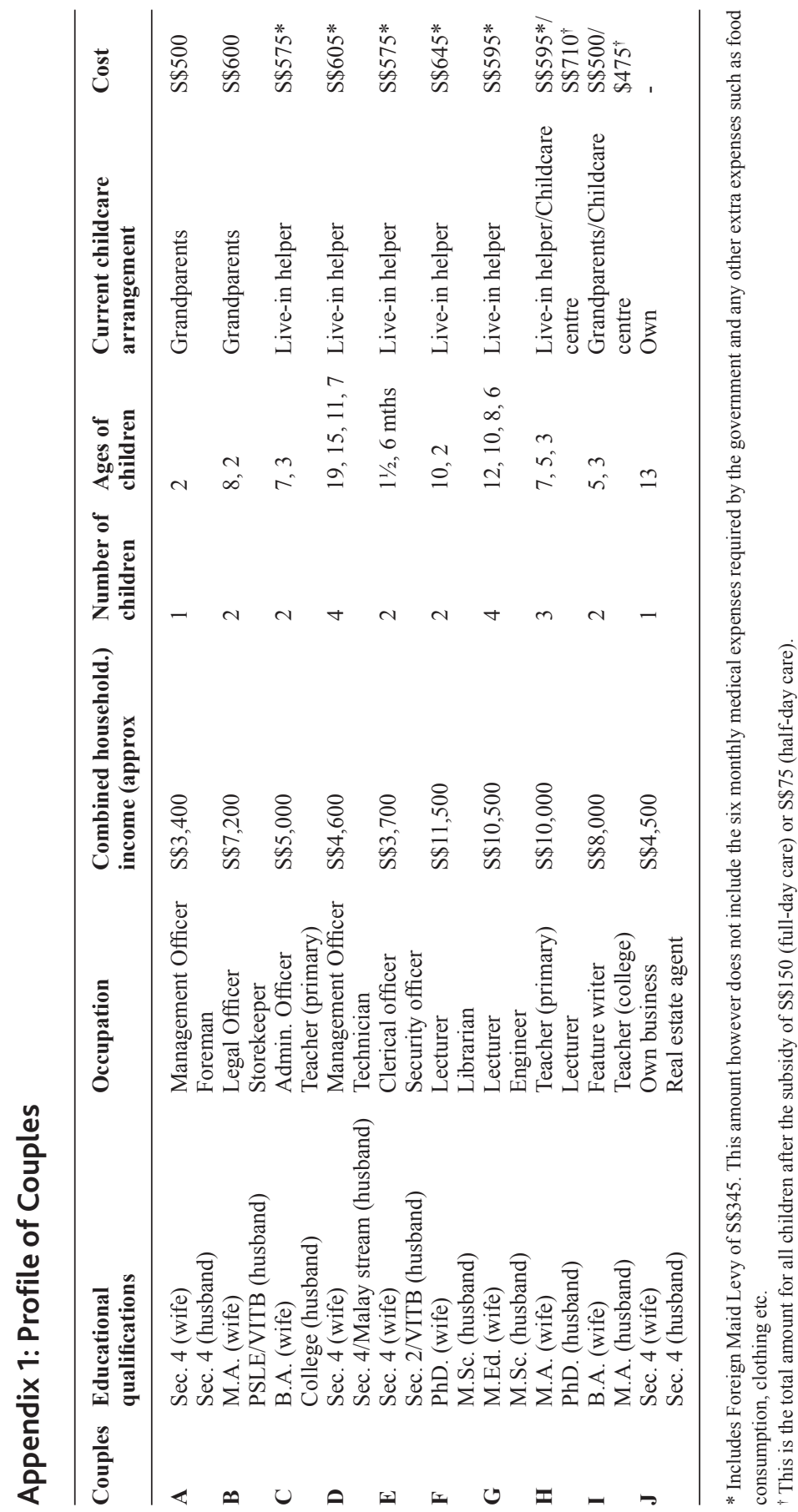




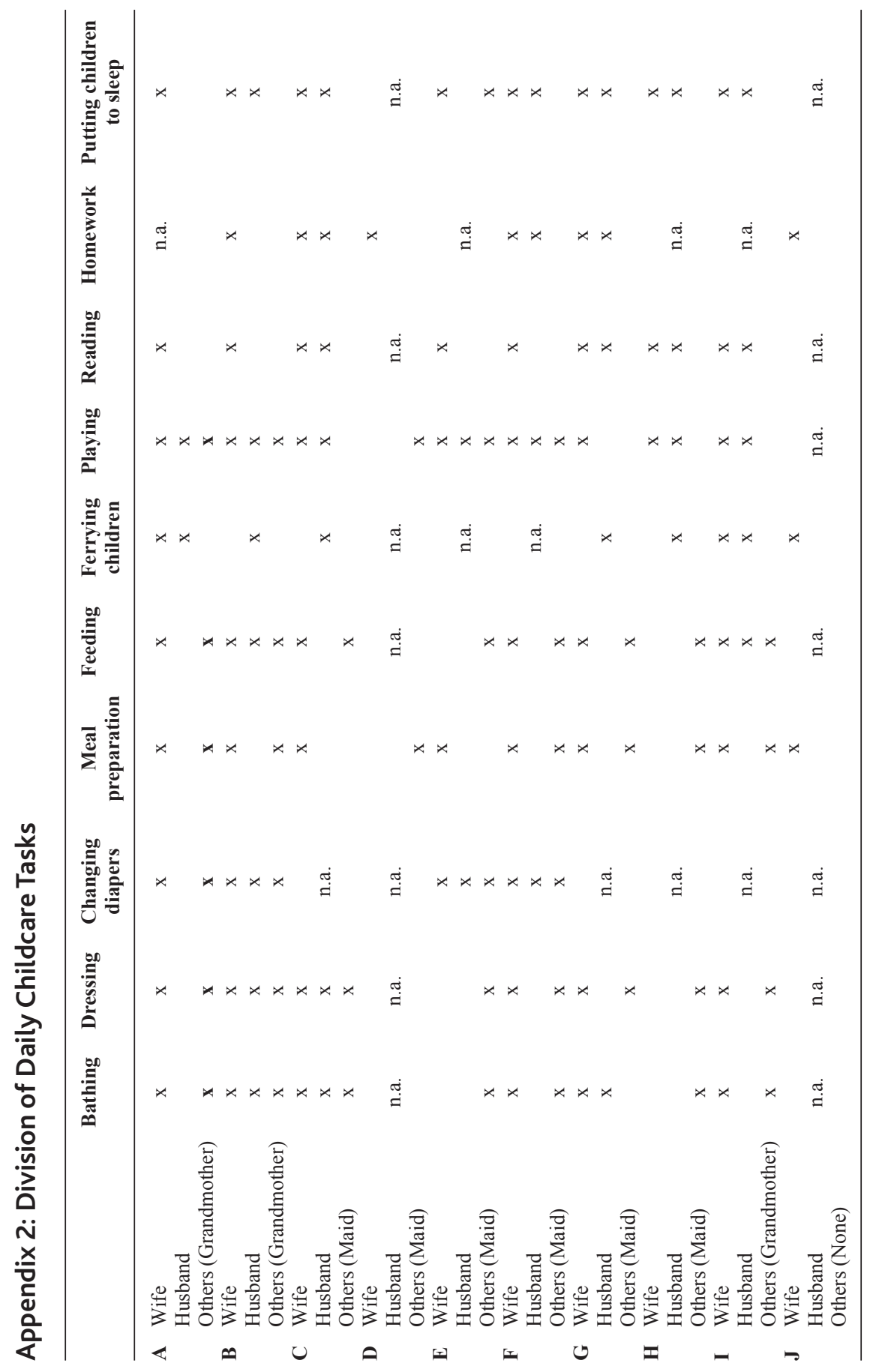

